\title{
Art, face and breathscape: From air to cultural texts
}

\author{
Silvia Barbotto ${ }^{1}$
}

\begin{abstract}
We consider breath as a vast prospect that includes actions and traces of them, that builds images and texts, that involves the human being and the extra-human context; we call this great scenery 'breathscape. We then study how breathscape interacts with the human apparatus of the face, both giving rise to signs, but also giving rise to a liminal zone of extremely intriguing interpretative processes on a mereological scale. How and where do the territory of breath and the body interact? Which processes of signification do they give rise to? And which signs are created in their phenomenal and semantic encounter? Art is certainly the most appropriate language for studying this process, as well as for letting opacities emerge and exploring outstanding contrasts. There are various concepts of 'breathscape' that, grounded in different cultures, are immediately associated with ancient and contemporary philosophies. As a reverberation from a semiotic interaction and through the discretization and identification of semantic fields relevant to the concerned scenario, and introducing textuality, a phenomenon seen as a crystallization of the transition between outer text (the text of reality) and text (subject/object), we consider those visual texts which are crossed by a common faculty that is both descriptive and inventive: by approaching some inferential and cultural regimes and analysing their specific enunciative practices, we then contribute to their renovation. The texts related to the practices as part of the narratives intrinsic to cultural semiospheres underline the insatiable vastness of epistemological content to be dealt with, and the functional reductionism of the corpus is only a first approach to the field that is intended to shed light on the general panorama and to stimulate subsequent debate and insights.
\end{abstract}

Key words: breathscape; semiosphere; cultural semiotics; translation; face; art

1 Department of Philosophy and Education Science, University of Turin (Unito), Italy; e-mail: silvia.barbotto@unito.it. 


\author{
“...como un lindo recuerdo \\ que se convierte en rostro \\ y yo sepa por fin \\ que dejas para siempre \\ la espesura de ese aire maldito..." 2
}

(Benedetti 1998: 84-85)

'Breathscape' is a vast prospect that includes actions and traces of breath, that builds images and texts, that involves the human being and the extra-human context; it is the landscape of breath, of the breathing and the breathable. As a semiosphere with a delimited character and semiotic irregularity certainly draws from its biological environment, it becomes an articulated multilevel process that involves cultural phenomena such as lifestyles, lived ambience, movements and reactions, both voluntary and involuntary. Just think of the contemporary pandemic period, which has shed light on the foundation of life, on the semiotization of the air we breathe as a transversal right but also as a language whose articulation is still partially to be discovered and recomposed as a cultural kaleidoscope.

Although in breathscape analysis it is necessary to mention reference to the ontological and biological aspects, we will focus instead on the critical semiotic one: by evoking not only the living status of the breathing human body, but also breath as a transversal, inclusive and fertile enclosure, we will turn to breath as a textualized scenario of being and expressing. It is, in fact, the object of specific articulations in manifestation of art or multimedia works as displays of signs left by its course, its movement or built through interaction with other texts, as traces left on the face, the one belonging to the breathing human body. The facial production of meanings, in its reciprocity with otherness and the context, occurs on multiple levels; we identify at least two: the object one analysed through the selection of a dedicated corpus, and the meta- one, focused on the language utilized, on the generation of the argumentation. The face-sphere as a system is a whole: we need to identify meaning-making monads and articulate, mereologically, mechanisms of translation.

It is precisely the face, in this case together with 'breathscape', that is at the heart of this article: we would like to explain, albeit not exhaustively, its role, its dynamic and processual signification, responding to the contemporary need of researching and understanding the face in different interconnected dimensions as, for example: "the predominance of the face in the neurophysiology of perception and cognition;

2 “...like a beautiful memory / that becomes a face / and I finally know / that you leave forever /the thickness of that cursed air..." (Translations from languages other than Engish are mine, unless indicated otherwise, S. B.) 
its impact on visual culture; its role in art as in portrait; the new aesthetic gender and formats of facial communication; the change of introspection, empathy and interaction in the face" (Leone 2021: 16). We are already starting to delineate the visage as a communicative interface with 'breathscape', a surface on which to express, transmit and perceive, but also as a live transitional platform, a seat of the ephemeral passage of components such as air which, besides having determinate chemical and physical characteristics, also becomes an interpretable instance of arbitrary nature, where the embodiment of automatization and de-automatization can be questioned. The face assumes the profile of a topographic countryside ${ }^{3}$ full of plateaus and mechanisms of intersemiotic transitions and translations, in which to understand and establish the borders between the different semiospheres, with references to physiognomy (Caroli 2012), anatomy, morpho- and neurophysiology ${ }^{4}$. Being rich in promontories and caverns, the visage is an expressive façade and visual screen of emotionality (Hwang Hyisung 2015); furthermore, density and emptiness of its constitution (the physical and the metaphorical one) establish the haptic mechanism of internal connectivity: the nose and specifically the nostrils, the mouth and the oral cavity are the main orifices through which we breathe, where breath transits, but all the pores of the skin breathe and a semiotics of action would be needed to crystallize its dynamics.

There is an array of notions that different cultures have adopted to know and describe the entire universe as a breathing one - we need only think of the pneuma of the Stoics, the prana of the ancient Veda texts, or the broader oriental term $Q i$, emblem not only of breathing but of the wider panorama of energy; metalinguistic attempts to unfold meanings about this cosmos are part of the efforts that accompany this exploration, too. However, the very wide range of cultural languages containing linguistic and comparative considerations will not

3 At this point, we recall a passage from Deleuze and Guattari for whom the development of the mechanism of faciality contains marked references to the concept of landscape: "All faces envelop an unknown, unexplored landscape; all landscapes are populated by a loved or dreamed-of face, develop a face to come or already past. What face has not called upon the landscapes it amalgamated, sea and hill; what landscape has not evoked the face that would have completed it, providing an unexpected complement for its lines and traits [...] The machine is already in place that always functions to produce faces and landscapes, however abstract" (Deleuze, Guattari 1987: 172-173). The authors bring to light various examples in which the intercut between face and landscape stands out in literature, architecture or cinema; although it leaves room for drift and uprooting, it nevertheless suggests, indeed, encourages, systems of re-territorialization, in a kind of 'visageité' not only of certain parts of the body, but also of objects of common use.

4 In this respect, we recommend watching the series "The science(s) of face" by FACETS ERC, organized by Viola Marco. 
be deeply examined; rather, the investigation will focus on artistic and aesthetic artefacts.

At one point, we will be focusing on the paradigm of visual culture, art and pseudoscience: selecting a few artistic texts and also drawing on physiognomy, we will create a corpus crossed by a common property that is both descriptive and inventive. These visual text travel in semiosphere, propitiating new experiences for the visionaries, and they are also re-created back: "Creative vision modifies these materials. They take their place in an unprecedented object of a new experience" (Dewey 1934: 89).

Based on the Lotmanian perspectives on culture and art, the article proposes relations with different interpretative semiotics currents and some methodological aspects regarding segmentation and selection which, once the isotopy of the breathscape as narrative background has been established, determines a programmatic body of work whose phenomenological origin is very heterogeneous: we find photographs of contemporary situations and performances, paintings, drawings, engravings. Even if this variety seems too discrepant, we could highlight that in all these manifestations of breathscape there is an evident reference to breath as a marked semiotic act, through the use of visual and verbal language; the reference to the face is also transversal, always present and mediated. While we are interested in emphasizing the discursive and discernible entity of the breathscape through the selection of texts, we also wish to emphasize the theoretical attributes of these texts and explore the consistency of their media in terms of materiality. "Semiosphere cannot come into contact with anything but texts, and texts are the products of semiosis. In this way, any contact with a space lying on the other side of a given semiosphere demands the preliminary semioticization of that space" (Lotman 2019[1989]: 91). Each text, a subjective object source, will be the bearer of a theoretical piece both on thematic path and on the medium itself: the creative processes underlying the text, as well as some of its significant aspects, will be partly highlighted, but, because it already is in itself, it will then acquire the totality formed in its continuity of being open to reading and interpretation.

It follows that the elements subsequently shared are, even if extremely simplified and still in the embryonic state of a necessary forward-looking path, partly representative of an initial approach of semiotics to the syntagmatic and paradigmatic articulation of the composition of the breathscape.

The identification of such discrete moments may recall the multiplicity of codification, the heterogeneous and multi-level property of textualities underlined in Lotman and Tamm (2019[1983]: 75): 
[...] every text is multiply coded (double coding represents the minimal structure). The conflict of thought formation arises not between individual textual formations but between languages manifested in text. Waves of syncretization of different arts [...] illustrate the two opposing tendencies characterizing this process. The structural parallelism of textual and individual semiotic characteristics allows us to define a text at any level as a semiotic entity, and to view an entity at any sociocultural level as text.

The following is divided into three parts: in the first part we approach the bodyface in relation with the environment, incorporating the individual and collective human actions in term of textuality. By entering another level of unity and complexity of meaning recognition, we then move to the language of art and description of dynamics texts. The third part will be dedicated to the relation between generalization and individualization process, by specifying cultural readings of air-signs on and of the visage.

\section{Body-environment interaction: Con-text, 'air as thing' and consciousness}

In the Lotmanian perspective the relation between the text and the context is proactive and co-generative: the text is intrinsic to its context and its provisional extrapolation happens only in speculative terms. For this reason, we briefly elaborate on the concept and artefacts in their individuality, being conscious that they are submerged in a more complex and formative process.

By introducing the suffix '-scape', we propose specific semantic features to the carrier token 'breath-', assuming the immersive and spatial attributes denoted in its extensive suggestions about the environment. 'Breathscape' is therefore a landscape of breath, a diffuse semiosphere, but epistemologically established in the circumscription of semantic manifestations; it is a semiospheric context, an inextricable and changing binomial (breath and landscape) composed in a pertinent and complex unitarian polyphony, governed by signs and laws that are not solid structures in themselves, "but fluid elements, which do change through history. A science of fluxes is needed to understand them fully" (Leone 2014: 117).

In fact, the proliferation of the '-scape' as a field of aesthetic analysis has been taking place since the end of the 20th century and, as Battistini (2020) warns us, it mainly concerns the five senses; he concentrates on the horizon of hearing and the audible as the path of the sense effects of the soundscape.

The compound word 'breathscape' provides that, thought of in more narrative terms, the object of its narrative programme is not a sense itself, but rather an 
a priori synesthetic field constituted in union and disjunction with the subject, intra- and extra-individual. It is this dimension made up of variable rhythms and densities, composed of more or less figurative fragments, expanded but at the same time necessarily intimate, that constitutes the environment to which we are referring and in which this specific textualization and semiotization of pieces of life takes place.

Distinguishing 'breathscape' as a language composed of texts, whose compositional and immanent signs are concentrated in a partially legible ensemble, in a kind of a dynamic "thing", as we recall from Genette (2010: 33) for whom 'things' are the stable (relatively immobile and durable) appearance that certain perturbations of atoms take on, which they nevertheless conduct under their continuous and untiring enduring aspectuality. In short, things are a particular kind of event.

We therefore go to the basis of the cultural semiotic point of view that considers culture as a system of languages and its concrete manifestations as texts, asking ourselves questions such as: How is the breathing landscape generated and translated? How and where do the signs of the flow pause? Is the face also a junction of text and context? Is it a platform where breathscape takes form and its development becomes explicit? Why is breathscape relevant from a semiotic perspective?

In this regard, Squarcini (2020) talks about the environment of breath in which we are immersed, a kind of "locus of daily setting" whose presence we praise and whose vital flow we invoke only when its normality is shaken up or the air is suddenly missing ${ }^{5}$. He also discusses the nature of this environment very thoroughly in his commentaries on the Patañjali Yogasūtra, II.50: “This is the general definition [...] of prānayyama: it is the confinement and analysis of the movement, the course, the 'natural' mode of exhalation and inhalation" (Squarcini 2019: 114, Comment 55). After having deepened the first three modalities (external, internal and suspended) of this practice, in Comment II.58

[...] the fourth type of prānāyāma is described, completely different and superior to the other three presented previously. [...] One thus passes from the act of confinement and vigilance over breath to the perception of the very form of the prāna, seeing the very intention of the confinement of breath disappear. (Squarcini 2019: 115)

\footnotetext{
5 This general idea comes from the interpretation of the lecture (Togliere fiato al respiro. Il prānàyama come non si è mai inteso) given by Federico Squarcini in the Chamber of the National Museum of the Risorgimento on 27 September 2020, during the 16th edition of Turin Spirituality Manifestation whose title was "Breath".
} 
From a semiotic point of view, some authors have already worked on the element air: for example, Jacques Fontanille (2008[2004]:160), relating it to the olfactory field, considers air the agent form of the actant of control: "air is in a sense the figurative vehicle of the powers of smell, weak but long-range if it is moving, strong and limited in range if it is stationary."

According to our interpretations, the breathscape, close to the definition of prāna, thus assumes an expanded character, with blurred topological dichotomies: the inside and the outside interpenetrate in a transient, thin, extended space. Here, however, we will deal with textual coagulations, practices and events that seem to condense, distort and modulate this spatiality, devising its borders more imprecise.

The first case reference deals with lack: having gone viral, the tag \#ican'tbreath comes to underline the urgency of a subordinate position in a racist cultural situation. Seen in narrative terms, the iconized phrase sums up and becomes viral, moving as a signifying manifestation. The epistemological framework adopted in this text settles as the figurativization of negation which, socially situated and shared, does nothing but strongly affirm the opposite side of the same isotopy, life. The modalization of the actants, once manifested in the conveying tag, highlights the passage from the mode of negation of power ('I can't') to the underlying modes of duty, of wanting, of knowing. The first-person singular shared in this way performs a hypostatized and inclusive act, indirectly implying the statement of a first-person plural. The images that appear on the web under this tag express the magnitude of a collective body that resists and fights by making its face manifest itself firmly.

The drama of George Floyd's death on 25 May 2020 is certainly a sensitive matter as well as a powerful communal issue, and although we do not deal with social ethnographic events like this, talking about air and human beings cannot but involve this very topical text and its widespread representations, and perceive them as paradigmatic. The formula \#Ican'tbreath creates an immense transmedia community in which the platforms and social networks become a contextual, informative and foundational venue: for example, \#icantbreath includes 1,250,628 publications on Instagram only as last consulted (on 19 February 2021).

To convey attention to the triggering of semiosis, its evolution in and with culture, propitiating a process of self-consciousness, including self-as-individual but also self-as-community, we remind the concept of personal knowledge treated by Lotman as the connection between objectual things and individuality where also absence and exclusion of the signs are vehiculated as well as the presence and inclusion of them. The signic cosmos is animated by a collective consciousness, and in "Toward a theory of cultural interaction: The semiotic aspect", Lotman (2019[1992]) argues that the elaboration and growth of the relation between 
individuality and the whole are dynamics synchronically animated by two kinds of consciousness, the logical one and the creative one, in any case a linguistic consciousness of the parts and of a whole, a semiospherical entirety:

There are real human collectives in which every individual unit has the urge to transform itself into a self-sustaining and unrepeatable world of its own while at the same time entering into a hierarchy of structures at ever higher levels, forming at every level a communal socio-semiotic entity, which, in its turn, enters into a more complex unities as a part. The process of individualization and generalization, or the transformation of the individual into an ever more complex whole and into an eversmaller part of that whole occur in parallel. (Lotman 2019[1983]: 74)

\section{Language of art and description of dynamic texts}

As part of everyday life, which Lotman calls 'byt', the arts as well as theatre (which is treated as an artistic practice in its own right) propitiate an intense exchange with the human being whose behaviour is continuously and intensely influenced by them. Remarking on the special features of artistic objects and bringing them closer to the prescription of things, we must, however, point out the dialogical and deeply generative nature of this choice, especially in the light of the fact that we are talking about a research object that is originally extremely changeable, the breath. As a secondary modelling system, art can also be described as a secondary language and, being a language, a stimulation for human consciousness, so art participates in modelling the consciousness apparatus. Language thus contributes to questioning the founding principles by propitiating, and in some way grammaticalizing, the creation and interpretation of the resulting textual expressions. Gillo Dorfles has studied the relation between perception, meaning and action and has attempted to identify the perceptive and cognitive data on which the present and future artistic experience is placed: his consideration are transversally close to this. In "The phenomenon of art", Lotman (2009: 150) made evident that

[T] he transformation, which occurs at the true moment of explosion, having been filtered by the lattice of the modelling of consciousness which converts the random into regular, does not as yet complete the process of consciousness. This mechanism must also include the act of memory, [...]. There are now, as it were, three layers of consciousness: the moment of primary explosion, the moment it is realized by the mechanism of consciousness and the moment of its redoubling in the structure of memory. 
Artistic texts, as part of a secondary language system, propitiate internal collisions that can explode into new significant structures and open up to the proliferation of further texts that on the one hand tend to integrate with the initial one, while on the other hand they are orchestrated in order to complete themselves as far as possible with the context again. This explosive subversion, the fulcrum of such languages, emerges from the innovative and propelling apparatus of visions other than the prevailing ones.

The conversion of natural language into alternative ritualized, represented, semiospherized formulas gives rise to new recipes encoded through cultural arrangements: the texts will therefore be a syncretism of different idioms that have a fluid and complex structure, that require a rhizomatic decoding process and that, by making the various structuring items equivalent, highlight the isotopic ensemble. If the texts, especially if they are artistic, are therefore integrated with their context of origin, they are also hijacked in the forward-looking contexts of destiny. Through cultural arrangements, art makes an explosive entrance into the contemporary world, launching condensations of alternative and innovative visions. In this respect we think of the works Body of Air (1959-1960) and Artist's Breath (1960) by the conceptual artist Piero Manzoni, who, being amongst the first to do so, identifies and circumscribes breath as an element of artistic reflection.

Didi-Huberman (2016[2005]: 8) emphasizes the relational nature of a "thing" called breath:

We only see it as a vital element - although it does not become an isolable 'thing' when it is polluted with dust, swirling in smoke, violent in turmoil or missing in drowning. We never feel it better - as matter, as a medium, as a necessity - than when impurity reigns and breathing becomes short.

In this recognition and attention to the outer text we approach breath as a thing, as text.

From among the multitude of artistic texts related to breathscape, we have chosen a few as representative of a general panorama, including different modalities, varying especially in the implication of the body and its relation with materiality; for this first research they are not yet systematized and synthetized in specific typologies, but have been approached instead through description, also considered an essential scientific issue (Lotman 2006), a modus operandi of a semiotic method (Migliore 2005).

The first example is Abramovich and Ulay's performance: Breathing in Breathing out (see Fig. 1). ${ }^{6}$

6 The performance is accessible on the YouTube platform https://www.youtube.com/ watch? $\mathrm{v}=\mathrm{rWixdA} 2 \mathrm{xTSs}$. 


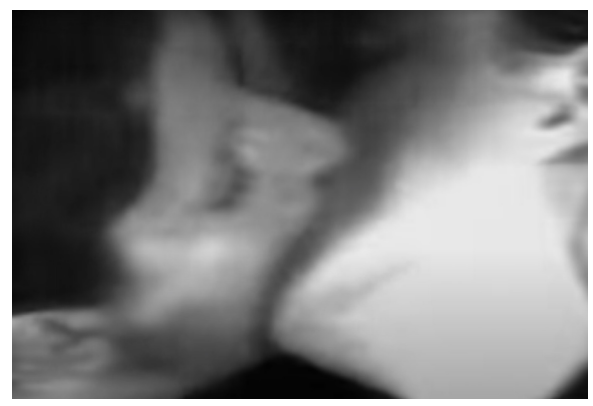

Figure 1. Abramovich and Ulay. Breathing in Breathing out (1977). Performance (videorecorded live/freeze frame), Student Cultural Center, Belgrade. Courtesy of Marina Abramovic and Sean Kelly Gallery New York.

The text air, modulated in the respiratory act denoted by the present participle of the verb in the title, ceases to be a natural pre-constituted substance and becomes a ritualized realm in which the whole action revolves, a constellation distributed on various paradigmatic levels. First of all, there is the binomial thing/artist: Abramovich's intimate relationship with Ulay, the fusion of the two bodies and their faces through shared breathing is sufficient until, at the seventeenth minute, the air becomes almost exclusively carbon dioxide and causes partial fainting of both protagonists. In the experience and ritualization of the moment, the receptors and the cultural sphere also participate in the founding and transforming constitution of new texts palpable not only in situ, but also in memory. The texts are subjects with many entangled layers.

The structural complication that spreads like wildfire from such a full-bodied artistic text nourishes the public, not only allowing new interpretations to take root, but also opening up ideological spaces that were previously airtight. When the artists are breathing into each other, the oxygen is reduced to zero and the increase of carbon dioxide leads to exhaustion: the culturalization of the moment, once the primary nature is gone, is not enough. Yet the action speaks volumes: the proprioceptive and metalinguistic character of the action, captivated and strengthened, becomes a voice for the generation of new meanings.

At the basis of this gesture, in the union of two faces whose mouths become one, in the dreamy deliberation of each other as sufficient life force and in the taking to the extreme of the attempt to transcend physiologically from the primary metabolic functions, there is the effort to access the unknown, foregrounding and therefore poetically operating on the axiological setting of those present.

The interpretative codes take on polyform dimensions and features, fleeting characters of sometimes static but constitutionally fluid illustrations, from mythical 
reminiscences and immersive ceremonies to rarefied and penetrating perceptions. The face alternates between subtle blasts of resistance and contrast, explosion and staticity, into the creative depths of a semiotic circle. Above all again fluidity, evoked breath that brings back to the lifeblood, zero degree on which and from which to operate.

The following piece (Fig. 2) is composed of photographs of the performance of running, an audiovisual installation with 26 sound speakers playing, each of them showing a part of the artist's breath (recorded during the performances) in a series of web podcasts:

Kanarinka ran the entire evacuation route system in Boston and attempted to measure the distance in human breath. The project also involves a podcast and a sculptural installation of the archive of tens of thousands of breaths. The project is an attempt to measure our post-9/11 collective fear in the individual breaths that it takes to traverse these new geographies of insecurity. ${ }^{7}$
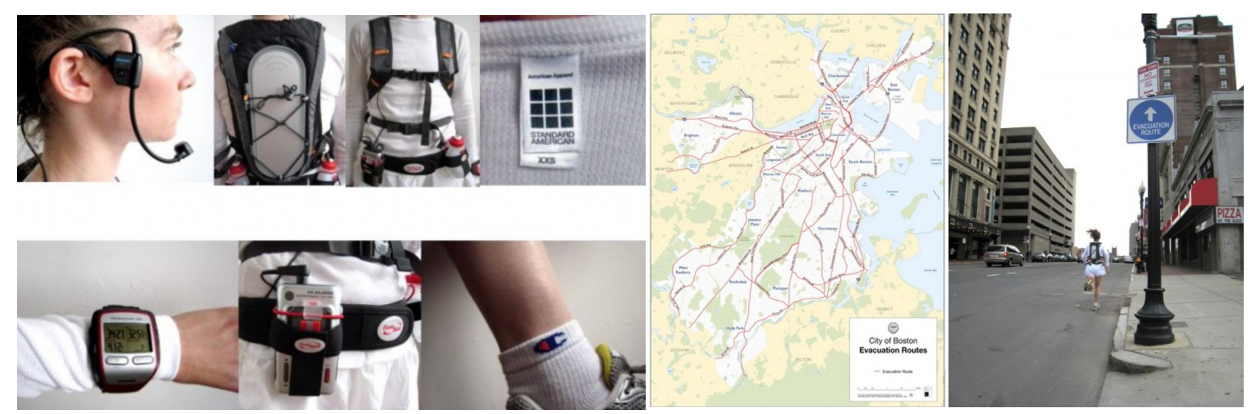

Figure 2. Kanarinka. "Running performance" (2007). Performance filmed as part of a bigger work titled It Takes 154000 Breaths to Evacuate Boston. Ensemble of visual records, screenshot from www.kanarinka.com (last viewed on 20 February 2020).

Like an archaeological artefact which is suspended in time and which has been recreated in space, according to Lotman an innovative text can precede the language and, searching for the codification between the real text (the outside text) and the text, we accomplish an act of reconstruction, proposing newest version of the same initial textuality.

In case of Kanarinka it is not only the face which is the protagonist, but the entire body. "The body, all of it and at all times, even in spite of itself, signifies. By itself and in the whole ensemble of its relationships the body constitutes a sort of

7 See http://www.kanarinka.com/project/it-takes-154000-breaths-to-evacuate-boston. 
"corposphere", which itself is an integrating part of the semiosphere." ${ }^{\text {The creative }}$ capacity of the performing body shapes texts that tacitly break into the ideological and molecular structure, triggering a trans-textual componential process in which a person and culture regenerate each other: Kanarinka's work of art reasons on the dominant political paradigms and proposes a critical reading of these.

Another artwork to be addressed here, by Lozano-Hemmer Rafael (see Fig. 3), is a hybrid between the categories of performance and installation: the body of the protagonist - their face and breath involved - is preponderant, but it is also, at the same time, great machinery in motion. It is a metaphor for perpetual movement.
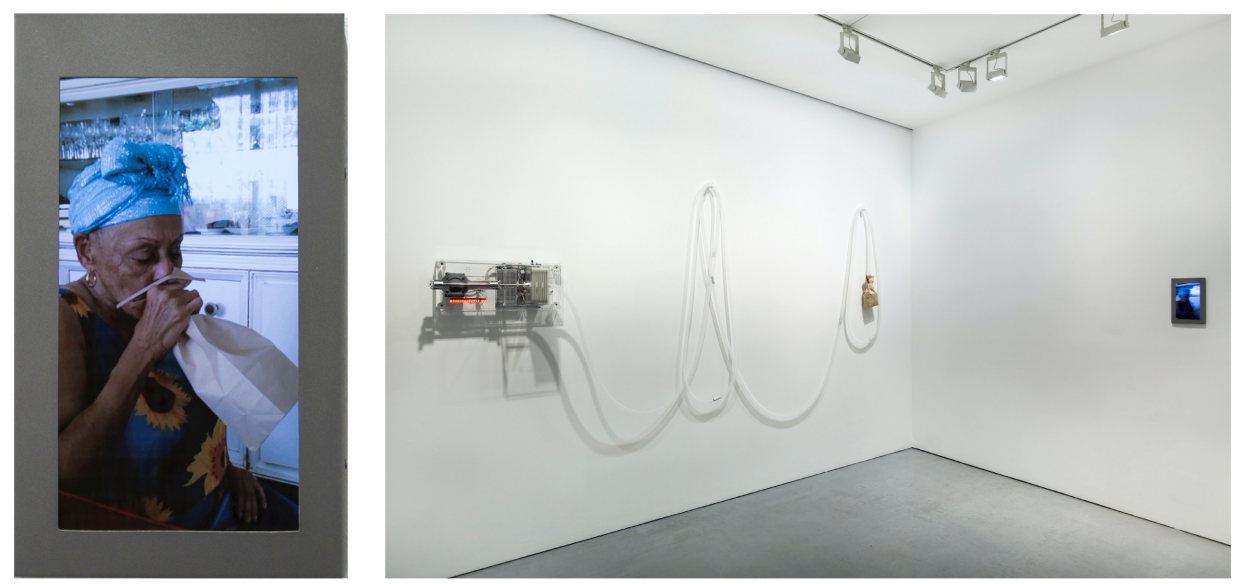

Figure 3. Lozano-Hemmer Rafael. Last Breath (2012). Sound installation: apparatus $60 \mathrm{x}$ $27,5 \times 23 \mathrm{~cm}$, tube up to $15 \mathrm{~m}$ long. Edition: 6 copies +3 AP copies. Photo by Grace Storey, Carroll/Fletcher Gallery. Courtesy of the artist.

This motorized installation allows the captured breath to preserve itself and last over time in an infinite, complex and constant duration: it does not remain static inside an inert box, but, simulating inhalation and exhalation, produces an organic sound determined by the cardboard bag in which the last breath was initially concentrated.

8 Finol Enrique in Semiotics of the Body, 2020. Virtual Series Facets available on Youtube, channel facetsERC, min. 2:47. 
On the artist's official website9, this piece is described as "A 'biometric' portrait designed to store and circulate the breath of a person forever, between a robotic bellows and a brown paper bag": the cold mechanical complex is accompanied by the sound act and a video that immortalizes the moment in which the chosen artist (in this case Omara Portuondo) leaves her "last breath". The storage of the most ethereal substance, the subjectification of the machine and the timeless alteration of the becoming allow punctuality to become durability, letting the poetics of the work absorb within itself the isotopy of life and its opposite, denoted above all by the title.

The landscape of air together with the intrusion and pervasion of space in the singular respiratory acts constitutes the syntax of the performance. This new text, the installation, is syncretic and multilingual, lives on the frontiers and spreads out in the interstices, every new text is somehow creative.

The frontier, once established, immediately aspires to be resemanticized and reabsorbed, shedding light on the areas of contact, collision and opening, thus revealing not only spatial and symptomatic considerations, but also those of an underlying or evoked effect. This is the case of the trace in the conceptual art piece Breath of Leaves (Soffio di foglie, 1979) by Giuseppe Penone: an imprinted area in leaves evokes an anterior presence, a body that was previously there. A simulacrum of an invisible body, the index of a material form that was once there, together with the shape of the leaves on the ground create the breath: as is typical in Arte Povera, of which Penone is a pioneer, poor materials with the predominant use of natural elements assume a new signification on both the planes of expression and of content, which seems to highlight an evident relation with ancestral and oriental art representation. Breath of Leaves recalls the privileged moment in which we and nature breathe together, generating a subtle aura that can be perceived when viewing a work like this. There are also two later works by the same author (see Figs. 4 and 5) with which Breath of Leaves can be grouped together for systematic purposes ${ }^{10}$. Some years earlier, in 1973, the Cuban artist Ana Mendieta started to develop and produced a similar work that would then be grouped in the Silueta series.

9 "Last Breath is an installation designed to store and circulate the breath of a person forever. The piece consists of a small brown paper bag which inflates and deflates automatically thanks to motorized bellows similar to those found in artificial respirators in hospitals. The apparatus hangs on a wall and is activated 10,000 times a day, the typical respiratory frequency for an adult at rest, including 158 sighs. Each stroke of the machine advances a digital counter that beeps. The breath circulates between the bellows and the paper bag through a ribbed transparent plastic tube that emits a faint and hypnotic low sound. The first copy of the piece stores the breath of Cuban singer Omara Portuondo." https://www.lozano-hemmer.com/last_breath.php (last accessed on 20 February 2020).

10 In the cycle of works Breaths (Soffi) and executed from 1978 onwards; the author retrieved from the world of mythology the image of breath as the origin of man and as a vital and energetic element, see: www.castellodirivoli.org/artista/giuseppe-penone/. 


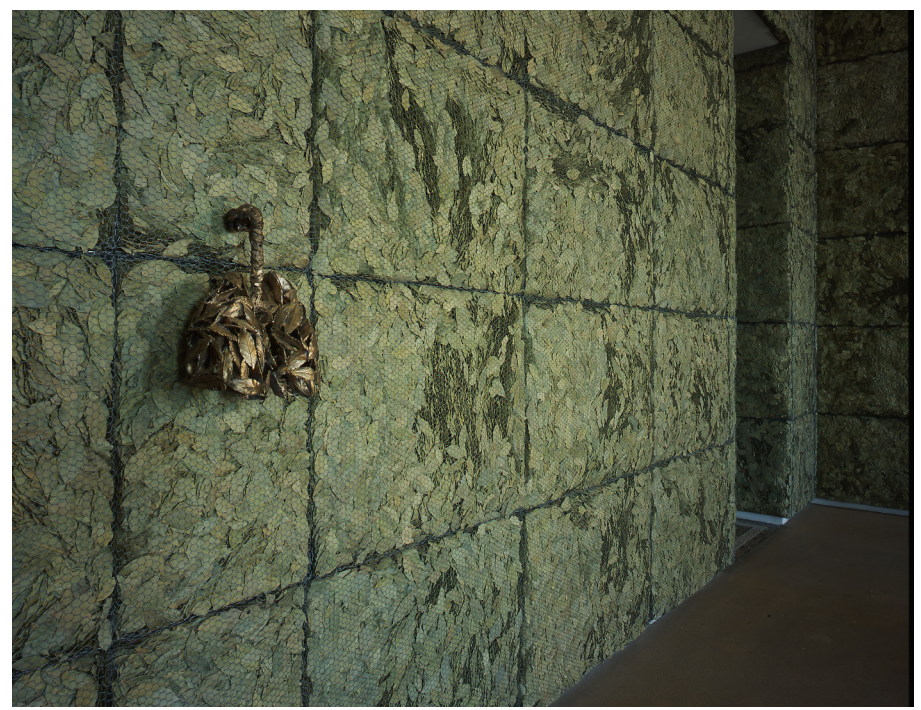

Figure 4. Giuseppe Penone. Breathe the shadow (Respirare l'ombra). (1999, installation: laurel leaves and gilded bronze.) Photography by Paolo Pellion. Courtesy of Castello di Rivoli Museo d'Arte Contemporanea, Rivoli-Torino.

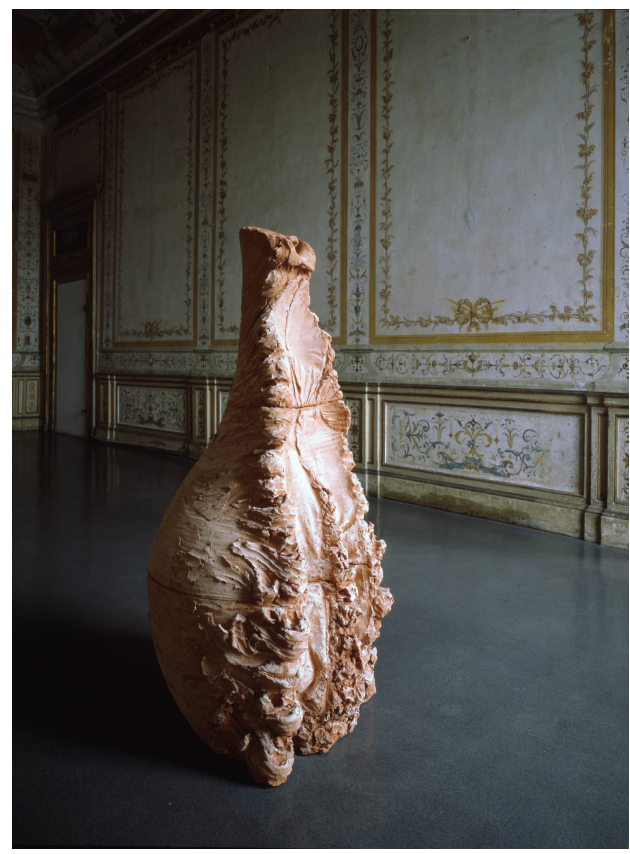

Figure 5. Giuseppe Penone. Breath of Clay (Soffio di creta). (1978, sculpture.) Photography by Paolo Pellion. Courtesy of Castello di Rivoli Museo d'Arte Contemporanea, Rivoli-Torino. 
A problematized philosophical category, the element of air moves from virtualized to actualized in the form of breath, which can be read in semi-symbolic terms. "Air [...] as the incessant exchange of 'life in the past' and 'life to come', of survival and the desire that is born from it. [...] Here, then, is the 'air in motion' that makes the protrusions of desire and the emanations of the farthest past co-present" (Didi-Huberman 2016: 30-31). Belonging to a single series entitled Breaths (Soffi) Penone's works highlight certain semantic traits whose interpretative keys of the figurative and the plastic would intersect. Breathe the Shadow is a multi-sensorial work that mainly combines the involvement of sight and smell in a reading path that can be addressed by syncretic semiotics, while Breath of Clay is a figurative sculpture. The isotopic significance of the work and the title can lead to the articulation of different perceived interpretations, but the figurative elements (the title, the lung, the leaf) together with the plastic ones suggest a system of relations connected with the 'breathscape'. It may be useful at this point to comment on a recurring lexeme, 'element', about which Leone poses questions and suggests answers. Asking what an element is in art, whether a work of art can be composed of elements and then going on to more specific questions, he states:

'Element' is a common word in several meta-languages, although usually associated
with some sort of mechanical functioning: 'element' makes one think of the components
of a mechanism or of a chemical compound. Metaphorically, its semantics can also be
extended to cover the functioning of parts of a non-mechanical whole [...] an element
of something is not something that expresses an autonomous intentionality and a
self-centered agency but something that is subservient to the agency of a greater
whole. (Leone 2018: 111)

In the next piece of art observed, the image as expressive substance (the portrait genre, the technique of oil painting, etc.) is the inspiration on which the artist bases his work: Tim Eitel (Fig. 6) typically uses photographs taken by himself that are then translated into painting.

The air, a propitious element for a metatheoretical reflection, and the face as a salient point for a semiotics of the body and of everyday life, of the space passed through, inhabited, emptied, come together in Tim Eitel's pictorial representation to talk about himself and, in doing so, rework the cultural assets: "The processes of individualization and generalization, or the transformation of the individual into an ever more complex whole and into an ever-smaller part of that whole occur in parallel [...], this is the same way every artistic text is formed" (Lotman 2019[1983]: 74). Artistic processes build a kind of self-contained whole renovated and integrated in reception for a more complex and comprehensive formativity. The pictorial aggregate assumes high semantic density due to its internal 
composition, but also within the more general characteristics of a properly pictorial structure; according to Maria Giulia Dondero (2014: 27), the enunciative level may vary according to the relationship between "enunciative levels according to the degrees of stabilization (support) and enclosure (edges) of the object of analysis".

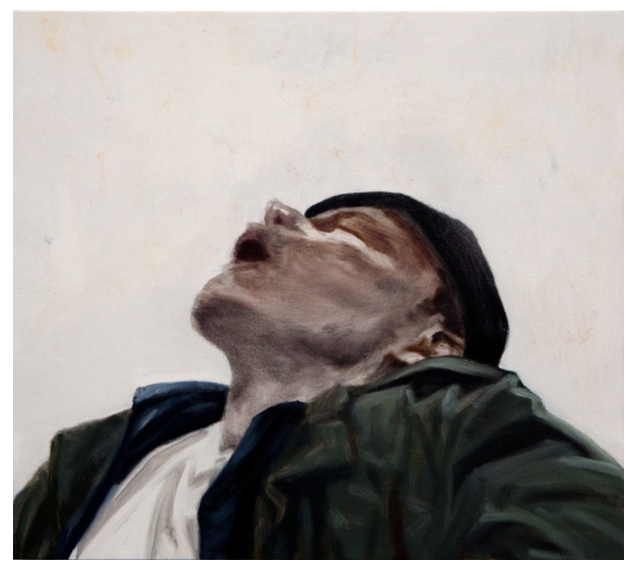

Figure 6. Tim Eitel. Untitled (Breath). (2009) Oil on board, 9" x 16”. Collection of Contemporary Art (Larry Qualls Archive). (c) 2014 Artists Rights Society (ARS), New York / VG Bild-Kunst, Bonn.

The receptacle face in Eitel's painting, emitter and receiver, synthesizes in a planar congregation the result of a stratification of pigments on the canvas; as the receptacle creator, the face becomes a reciprocal relation, and its orifices, the seven passages, furnish the power to channel the transition outside $\leftrightarrow$ inside, consenting the incorporated fuel to burn and distribute life and the unnecessary material to be expelled. The open mouth, which is the punctum in the level of expression of the painting, can evoke a moment of sleep, but also a possible fainting, close to representing death in the phenomenal macro-isotopy of human beings.

Mediating between Lotman's cultural semiotics and the propensity for Greimassian generative semiotics, Calabrese (2006) proposes deep narrative paths in which "meaning is generated through a general architecture that gives order to its internal components, one in relation to the other", involving epistemic and passionate dimensions of sensory experience. He elaborates theoretically on the element water and objectifies it as a "figurative phenomenon on the level of the manifestation of a text" (Calabrese 2006: 31-33). As a special figure of water, different kinds of materials, drawing on encyclopedic and lexical definitions, manifestations and figurative effects have been synthesized in the dichotomy 
representation/ostension of the following oppositional terms: transparency/opacity, projection/distortion, internal geometries (structure/lack of structure), movement/ immobility, punctuation/durativity. "Figurality is formed by categorial sets placed on the plane of expression of the semiotic system created by a text (especially visual), and able to combine with categorial sets belonging to the plane of content" (Calabrese 2006: 46).

In connection with the opposites of movement/immobility examined by Calabrese we can also mention the speed/slowness dichotomy in another author, Italo Calvino. This writer finds in speed and movement the possible reasons why a story can fascinate us and considers them to be the basis of the narrative links between desired objects. Movement, be it rapid or slow, is marked by rhythm, and the succession of events in a discourse that is not always linear, their gait and their conjunction establish the moving and stopping, "two operations on the continuity and discontinuity of time" (Calvino 1988: 32). The theoretical contributions concerning the temporal dimension are therefore highlighted as a rhythmic multiverse in which aspectuality, assimilation more or less intense or thinned out in time, provides evidence of the biological apparatus of the air represented as well as breathed.

That sphere of manifestation which would not belong to figurativeness, would instead be part of the semi-symbolic category due to the preponderance of the plastic signifier as happens in the following art works by Kenneth Noland and Richard Pousset-Dart (Figs. 7 and 8):

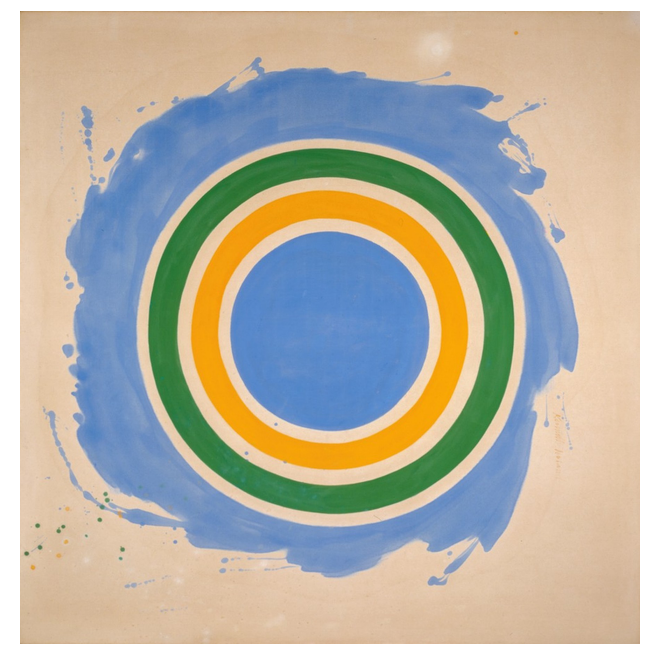

Figure 7. Kenneth Noland. Breath (1959). Acrylic on canvas. $168 \times 165.6 \mathrm{~cm}$. (C2020 The Kenneth Noland Foundation / Licensed by VAGA at Artists Rights Society (ARS), NY. 


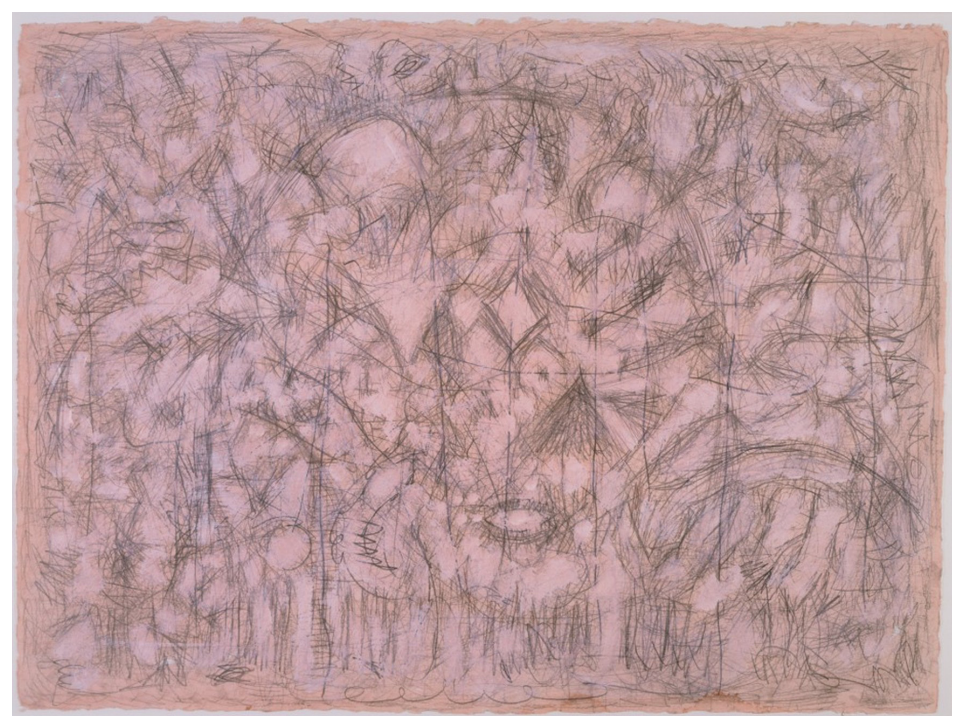

Figure 8. Richard Pousset-Dart. Breath of White Motion. (1990, works on paper: wash, pencil and acrylic.) 57.15 x $76.835 \mathrm{~cm}$. (C) 2008 Estate of Richard Pousette-Dart/Artists Rights Society (ARS).

Following Greimas, Collins and Perron (1989: 635), figurativity seems to go beyond the limits of the vehicle or support upon which the manifestation of a visual object is based: indeed, they emphasize that in addition to figures of expression, there are also figures of content.

In case of Noland's geometric and symbolic reference, the circle as a figure belonging to the world is evident, and although its reading is open and less explicit, if it is accompanied by the verbal discourse of the title, we can certainly open up interpretative and pertinent paths.

In contrast, the signifier in Pousset-Dart's graphic work is merely plastic: the graffiti lines on a monochromatic background organize an abstract scene which timidly suggests distant figures; the processuality highlighted by the strokes, between childlike grapheme and architectural projectuality, suggests dynamism and the emergence of possibilities, also interpretative ones. In Greimassian terms, this work can be read through the use of topological qualities which, between the straight line and the curved line, create a grid on the plane of expression that is further made discrete by the frame that has "a twofold function: the segmentation of the whole into discrete parts and the mapping out of the possible trajectories that the various aspects of the reading will follow" (Greimas, Collins, Perron 1989: 638).

In both cases, the semantic contribution of the titles should be considered as a determining and integrated component from which an isotopic construction that envelops and involves text-image would result. 


\section{Cultural readings of air-signs on and of the visage}

From the semiotic mechanisms that are highlighted in artistic texts we can now turn to those that, arising from the organic interaction between face and breathing and established in specific cultural memories, dictate original languages whose decoding is emblematic, for the very reason that they contain within them multiple gestational and interpretative approaches. As Lotman has pointed out, the collective intelligence of culture and individual consciousness travel together to generate meaning.

The impossibility of establishing univocal deductive relations of contact and interaction between the face text and the air text makes the relational practice ambiguous and difficult to codify: not only the cultural attributes, but also the independent operations of the intertexts and intratexts contribute to creating the specificity to be explored. Some cultures, however, have made their contributions through the elaboration of codified diagrams, dictionaries and even pseudosciences: physiognomy, for instance, has proved to be among the most equipped of these kinds of systematizations, but its affirmation has varied according to the geographical locations and historical moments in which it was developed. Patrizia Magli traces a foundational path regarding the system of physiognomy by identifying its various salient phases and crossing all the cultures that have employed it. Although it is still being practiced today, it is often referred to as a thing of the past:

Physiognomic competence originated in history as a form of knowledge determined by concrete needs. It is part of that circumstantial paradigm in which a constellation of disciplines participated in antiquity, such as divination and medical semiotics in its double function, diagnostic and prognostic, disciplines that shared a similar attitude oriented towards the analysis of individual cases, reconstructable only through traces, symptoms, clues. (Magli 2004[1995]: 26)

The author recounts how in Mesopotamian culture the face, formally composed by a meticulous reading of its formal micro-components, was an omen in divination, frequently rich in omens, in other words, accessible during ritualistic fields and subtle dedicated states of mind: some extracts are presented in Ludlul beel nèmeqi, an old sapiential manuscript that contains cults and ceremonies. The ancient Greeks, however, proceeded by means of clues, called tekmairesthai, which suggested relationships with the invisible: especially in the case of illness, the expert studied the dissimilarities that emerged (denoted by sweating, the sound of the voice, breathing, etc.) and they knew that a real Hippocratic facies would emerge when death was imminent. 
It is interesting to note how even in this period we begin to speak not only of the sequence of anamnesis-diagnosis based on the observation of the body and especially the face, but especially on how "the environment influences the physique and, consequently, the character" (Magli 2004[1995]: 40), as among the works resulting from such studies we find Le arie, le acque, iluoghi (end of the 5th century B.C.) contained in the Corpus Hippocraticum. Magli also delves into Arab physiognomy, whose "origin is lost in the mists of time, confused with that of magic, anatomy, physiology, philosophy but, above all, with that of medical art" (Magli 2004[1995]: 44); this is found in the term 'firāsa', a kind of "organ of circumstantial knowledge" with which only a few sages and mystics were endowed: it was an intuition capable of abductively interpreting not only the signs of the face, but also the clues hidden in the soul and the cosmos. There were various versions and updates of these practices, so much so that it continued until the beginning of the 13th century with the prestigious Kitab al-Firāsa of Fakhr al-Dīn al-Razi, a systematization of Arabic physiognomies.

In the West, this science was part of the apparatus of sign theories and astrology until the middle of the 17th century, when there occurred a separation between an astrological and a natural physiognomy:

The gaze passes through the surface of the body, the anatomy penetrates the inner man [...] Thus Cureau de la Chambre, who in his Art of Understanding People distanced himself somewhat from the "chiromancer", considered it still important for a doctor to take astrological signs into account. [...] Planets and signs of the zodiac in astrological physiognomy, moods and temperaments in natural physiognomy, in no way exclusive of each other, remain the guarantee of what is at the basis of the science of the face: the analogy of soul and body. (Courtine, Haroche 2007[1988]: 71-72)

With the Cartesian philosophy, also reported in Charles Le Brun's studies, paintings and Expressions of the Passions of the Soul, the organism entered the foreground and the machine-man typology succeeds the zodiac-man one. The representation of the signs that had been considered pertinent to the physiognomy earlier, became concerned with geometry, anatomy and medicine. Later, among some 19thcentury authors including Cesare Lombroso, there was an epistemic degeneration, a manipulation of information resulting from a reading of appearances that undermined these and stimulated racism.

It is clear that all these practices were extremely impregnated with the ideological thought in which they developed chronotopically, finding particular prestige or falling into decline, sometimes developing as conjecture and sometimes as science, but always implying a strong relationship between the face and natural 
elements. It would be interesting to understand if and how a semiotics of the elements is developed in various cultures; however, this study is limited to the element of air formalized to the face. ${ }^{11}$

Every culture has developed a different cultural memory with respect to this theme and seems to occupy positions that are currently rather distant from each other as regards the reading of signs on the face through physiognomy: some cultures have entirely abandoned such practices, but in some others the behavioural and relational signs between the physical body and the astral body are alive and readable. According to contemporary Chinese medicine, for example, the vital energy called $Q i$ has an abstract entity, but tangible repercussions: as, firstly, its signs can be read on the face; and, secondly, it can be dispersed but also invigorated through two main practices:

If Jing is the inherited fundamental energy, then Qi is the manifestation of that energy necessary to participate in the world. This implies exertion and movement or yang action. Qi can easily become overused and deficient, but luckily it can also be manufactured. There are two classic ways that you can make Qi buffer the use of Jing. The first way is by transforming food and the second is by transforming breath. However, this is more than just eating and breathing. Both of these ways of making Qi can be seen on the face and these horizontal markings are on the central meridian of the face across the nose and across the philtrum. (Bridges 2012: 24)

Marked lines above the lip area would therefore seem to indicate that "it is expected that some Jing will have been used up by these ages, but in order for Jing to be available for the remainder of life, a person with any of these lines should actively start making Qi with conscious intent as the Jing is not as strong as it used to be and needs support" (Bridges 2012: 24).

The memory of culture is identified by Lotman as a very important function of a text that, however, constitutes only a reduced mnemonic programmes (Lotman 1996). Face as memorial text, physiognomy as the reading of characteristic and permanent sign whose trace has been sedimented on the face in the memory of time, are part of the mnemonic programme of culture, and the Chinese culture is still benefitting from studying and applying it. As we have already seen, memory is the necessary building block for the initially explosive and then conscious phenomenon of art to take root.

11 In this regard, we would like to go deeper into Magli's (2004[1995]: 51-60) text, which, while also investigating other authors, reports on the semiotic Greimassian square of elements. 
From the point of view of semiotics, culture represents collective intelligence and collective memory, that is a supra-individual mechanism for preserving and transmitting messages (texts) and for creating new ones. In this sense, the field of culture can be defined as a space of shared memory, within which certain common texts are preserved and actualized. (Lotman 2019[1985]: 133)

So, actually memory is dialectical and its settling is not definitive.

In most of today's Western contexts, the coding system of physiognomic pseudo-science does not provide an informational setting for understanding its language, but it did so in the past. The decoding of the signs on the face, if it were to happen, would certainly not have the same resonance in different cultural environments. Thus, awareness should be raised concerning this subject, getting closer to oriental cultures that have maintained the dynamics of identification, reading and manipulation of the element 'air' in relation to the face in their memory.

The text later exposes some techniques and decodified readings, but what interests us is understanding how this occurs, especially in ancestral philosophical and medicinal practices, and in those ancient philosophies that have lasted to the present day affirming that the signs of the body can be read.

In the interpretative possibility resulting from a reading of the face, the ideological and cosmological background of the cultures under examination is highlighted. The use of semantic and typological categories refers to specific connotations regarding the air, the respiratory act, and the breathscape, while their perimeter is not limited to the surrounding context, but greatly amplifies the range of action, thus expanding the multidimensionality of the semiosphere. Where are the frontiers of this? What measurements are appropriate for them? How can the matter of body and air be scientifically correlated with the creative processes described above? Do the body and the face have memory?

In Chinese medicine a line on the face evokes the cosmos, explaining such a relationship on the basis of its features: an interpretative convention that approaches the "thing" by touching it, making it intelligible and partly favouring its direct contact. This line is:

[...] the highest point of the Chong Mai, which regulates the connection between Qi and blood and is the bridge between heaven and earth-breathing cosmic Qi into the body. [...] At the simplest level, a marking here shows the need to breathe properly, to expand the lungs and to oxygenate the blood. On a higher level, it means to expand your consciousness. A line in this area indicates that you have used up Jing and that the best way that your body can make Qi to compensate for that loss is by breathing in Cosmic Qi. (Bridges 2012: 27) 
South-Asian yogic cultures also propitiate a continuous dialogue with these extraindividual forces, and textualizations may be evident on the historicized face, but it is also interesting to study the performative face during specific uses of air as in kryia such as vātasāra, or during the practice of breathing called pranayama ${ }^{12}$. It would certainly be extremely fascinating to study the yogic face in terms of textuality, but to underline the importance of the practical aspect preponderant in these disciplines, we quote Squarcini's words who, recalling Merleau-Ponty's thought, insists on "practice that makes knowledge" rather than on "knowledge that orients practice": it would therefore be up to the semiotics of the body and of practice, or perhaps applied and implicated semiotics, to pursue this question, which has so far only been sketched out here and is open to future study (Squarcini 2019: CVII-CVIII).

\section{Conclusion}

Recognizing, reading and evaluating the signs of the breathscape as well as savouring the processes of its signification is an act of a continuous intersemiotic translation. The textualization of the landscape of breath must pass through different operations and from an elementary, natural, forgotten action it can become a crucial aspect of new forms of life and new figures of art. During the transition from text to language, its interpretation and therefore signification assume partial correspondences and mainly bodily statements. Tangentially to thought, breathing itself can be considered mediated by cultural language, as we can see in Torop's words on Lotman's Universe of the Mind: "Lotman's approach to the culture includes the notion that thinking is mediated by language, but dialogue occurs in cultural space" (Torop 2020: 267).

Breath can be read as a synecdoche par excellence that leads from one element (air) to the whole (life). Many texts from all cultures make references through intertextuality, paratextuality, metatextuality, hypertextuality and architextuality to the passage of breathing and its immensity: to conclude, we may remember the song "Breathe" from Pink Floyd's album Dark Side of the Moon (1973): "Breathe, breathe in the air/Don't be afraid to care/Leave, don't leave me/Walk around and choose your own ground."

The ether and the earth have always been the great dichotomous hemispheres whose reading on the surface brings out the semantic opposites of above and below, light and dark, light and heavy. Here, air and ground both assume the peculiarity

12 In this regard, we suggest viewing the images in specialized yogic texts or reading the extremely figurative and detailed explications in texts such as Saraswati, Swami Satyananda; Saraswati, Swami Niranjanananda 2013. 
of being carriers of freedom of action, the basis of that decisional act in which the breath, instead of being a natural act and simply perceived, is a conscious action and the constructive foundation of ground on which to move openly.

"Souvent décrit comme la zone la plus fragile et la plus nue du corps humain, le visage passe pour exprimer la vérité profonde des êtres. Or c'est justement parce qu'il se trouve en permanence exposé, impliquant ainsi toute la personne, quà la fois il se livre e se refuse aux regards."13

(Guedron 2015: 8)

Acknowledgement: This reseach is part of a project that has received funding from the European Research Council (ERC) under the European Union's Horizon 2020 research and innovation programme (Grant agreement No 819649 - FACETS).

\section{References}

Battistini, Emiliano 2020. Tra Soundscape Studies e semiotica: dall'effetto sonoro agli effetti di senso dellambiente sonoro. $E \mid C$ (Serie speciale) 28: 1-17.

Benedetti, Mario 1998[1996]. El amor, las mujeres y la vida. México D. F.: Alfaguara.

Bridges, Lilian 2012. Face Reading in Chinese Medicine. Edinburgh, London, etc.: Churchill Livingstone, Elsevier.

Calabrese, Omar 2006. La forma dell'acqua. Ovvero: come si "liquida" la rappresentazione nell'arte contemporanea. Carte Semiotiche 9/10: 57-66.

Calvino, Italo 1988. Lezioni americane. Sei proposte per il prossimo millennio. Milano: Garzanti.

Caroli, Flavio 2012[1995]. Storia della fisiognomica. Arte e psicologia da Leonardo a Freud. Milano: Mondadori Eclecta.

Courtine, Jean-Jacques; Haroche Claudine 2007[1988]. Histoire du visage. Exprimer et taire ses émotions (XVI ${ }^{a}$-début XIX ${ }^{a}$ siècle). Paris: Payot \& Rivages.

Deleuze, Gilles; Guattari, Félix 1987[1980]. A Thousand Plateaus: Capitalism and Schizophrenia. (Massumi, Brian, trans.) Minneapolis, London: University of Minnesota Press.

Dewey, John 1934. Art as Experience. New York: Perigee.

Didi-Huberman, Georges 2016[2005]. Gestes d'air et de Pierre. Corps, parole, souffle, image. Paris: Les éditions des minuit.

Dondero, Maria Giulia 2014. Sémiotique de l'action: textualisation et notation. Cadernos de Semiótica aplicada 12(1):15-47. https://doi.org/10.21709/casa.v12i1.7117

Dorfles, Gillo 2004[1959]. El devenir de las artes. México: Fondo de cultura económica. Genette, Gérard 2010. L'ouvre de l'art. Immanence et transcendance. Paris: Seuil.

13 "Often described as the most fragile and naked area of the human body, the face is considered to express the deepest truth of beings. Yet it is precisely because it is permanently exposed, thus involving the whole person, that it both reveals itself and refuses to be seen." 
Greimas, Algirdas Julien; Collins, Frank; Perron, Paul. 1989. Figurative semiotics and the semiotics of the plastic arts. New Literary History 20(3): 627-649. https://doi. org/10.2307/469358

Guedron, Martial 2015. Visage(s). Sens et representations en occident. Paris: Hazan.

Hwang Hyisung, Matsumoto David 2015. Evidence for the universality of facial expressions of emotion. In: Mandal, Manas K.; Awasthi, Avinash (eds.), Understanding Facial Expressions in Communication. New Delhi: Springer, 41-56. https://doi. org/10.1007/978-81-322-1934-7_3

Leone, Massimo 2014. Cultural semiotics as fluxorum scientia. In: Bankov, Kristian et al. (eds.), New Semiotics: Between Tradition and Innovation. Sofia: IASS, 112-130. https:// doi.org/10.24308/iass-2014-009

Leone, Massimo 2018. Designing imperfection: The semiotics of the pixel. Punctum 4(1): 105-136. https://doi.org/10.18680/hss.2018.0008

Leone, Massimo 2021. Esteticas faciais nas sociedades digitais contemporaneas. In: Teresco Vilardo Abreu, Maria Teresa; Carvalho Correia, Claudio Manoel de (eds.), Contribuicoes da Semiotica ao ensino de portugues no mundo. Rio de Janeiro: Dialogarts, 13-22. http:// hdl.handle.net/2318/1777594

Lotman, Juri M. 2009. Culture and Explosion. (Grishakova, Marina, ed.; Clark, Wilma, trans.) Berlin: De Gruyter Mouton.

Lotman, Juri M. 2019[1983]. Toward a theory of cultural interaction: The semiotic aspect. In: Tamm, Marek (ed.), Culture, Memory and History: Essays in Cultural Semiotics. (Baer, Brian James, trans.) Cham: Palgrave Macmillan, 67-81. https://doi. org/10.1007/978-3-030-14710-5_5

Lotman, Juri M. 2019[1985]. Memory in a culturological perspective. In: Tamm, Marek (ed.), Culture, Memory and History: Essays in Cultural Semiotics. (Baer, Brian James, trans.) Cham: Palgrave Macmillan, 133-137. https://doi.org/10.1007/978-3-030-147105_9

Lotman, Juri M. 2019[1989]. Culture as a subject and its own object. In: Tamm, Marek (ed.), Juri Lotman - Culture, Memory and History: Essays in Cultural Semiotics. (Baer, Brian James, trans.) Cham: Palgrave Macmillan, 83-93. https://doi.org/10.1007/9783-030-14710-5_6

Magli, Patrizia 2004[1995]. Il volto e l'anima. Fisiognomica e passioni. Milano: Edizione CDE.

Marchianò, Grazia 1977. La parola e la forma. Bari: Dedalo.

Migliore, Tiziana 2018. La procedura di descrizione. $E \mid C$, On-line Journal of Aiss.

Polacci, Francesca (ed.) 2012. Ai margini del figurativo. Siena: Protagon editori.

Saraswati, Swami Satyananda; Saraswati, Swami Niranjanananda 2013. Prana vidya. Munger, Bihar, India: Yoga Publications Trust.

Squarcini, Federico, ed. 2019[2015]. Patañjali Yogasūtra. Torino: Nuova Universale Einaudi. Torop, Peter 2020. The chronotopical aspect of translatability in intersemiotic space. Punctum 6(1): 265-284. https://doi.org/10.18680/hss.2020.0013 


\section{Искусство, лицо и дыхание: от воздуха до текстов культуры}

Мы рассматриваем дыхание как обширную перспективу, которая включает в себя действия и их последствия, которая создает образы и тексты, которая включает в себя человека и окружающую среду; мы называем это «пейзажем дыхания». Затем мы изучаем, как «пейзаж дыхания» взаимодействует с человеческим лицевым аппаратом, порождая знаки и крайне интригующие интерпретационные процессы на мереологической шкале. Как и где взаимодействуют территория дыхания и тела? Какие процессы означивания они порождают? Какие знаки создаются в ходе их феноменальной и семантической встречи? Искусство, безусловно, является наиболее подходящим языком для изучения этого процесса, так как позволяет проявлять и исследовать контрасты. Существуют различные интерпретации «пейзажа дыхания», которые в разных культурах ассоциируются с древними и современными философскими течениями. В качестве отголосков семиотического взаимодействия и посредством различения и идентификации семантических полей, относящихся к рассматриваемому сценарию, введения текстуальности как феномена кристаллизации перехода между внешним текстом (текстом реальности) и текстом (предметом/объектом), мы рассматриваем те визуальные тексты, которые являются одновременно как описательными, так и изобретательными. Затем мы рассматриваем некоторые выводимые и культурные режимы и анализируем их конкретные практики, внося этим свой вклад в их обновление.

\section{Kunst, nägu ja hingusemaastik: õhust kultuuritekstideni}

Käsitleme hingeõhku avara väljavaatena, mis sisaldab tegusid ja nende jälgi, mis loob pilte ja tekste, mis hõlmab inimesi ja inimvälist konteksti; seda laia maastikuvaadet nimetame "hingusemaastikuks". Seejärel vaatleme hingusemaastiku vastastiktoimet inimliku näoaparaadiga, milles mõlemad kutsuvad esile märke, aga tekitavad mereoloogilisel skaalal ka äärmiselt põnevate tõlgendusprotsesside liminaaltsooni. Kuidas ja kus mõjutavad teineteist hinguse territoorium ja keha? Milliseid tähistamisprotsesse nad esile kutsuvad? Ja milliseid märke nende tajutavas ja sematilises kohtumises luuakse? Kunst on kahtlemata kõige kohasem keel selle protsessi uurimiseks ja ka varju jääva esile toomiseks ning silmapaistvate kontrastide vaatlemiseks. On olemas mitmeid "hingusemaastiku" mõisteid, mis erinevatest kultuuridest tulenevatena koheselt seostuvad kas iidse või nüüdisaegse filosoofiaga. Semiootilise vastastiktoime järelkõlana ning asjakohase stsenaariumi suhtes oluliste semantiliste väljade eristamise ja tuvastamise kaudu ning tuues sisse tekstuaalsusnähtuse, nagu seda on välisteksti (reaalsuse teksti) ja teksti (subjekti/objekti) vahelise ülemineku kristalliseerumine, uurime neid visuaalseid tekste, mida ühendab joon, mis on niihästi kirjeldav kui ka leidlik. Seejärel võtame vaatluse alla mõned inferentsiaalsed ja kultuurirežiimid, analüüsime nende eriomaseid enuntsiatiivseid praktikaid ning aitame seeläbi kaasa nende uuendamisele.

Tekstid, mis on nende praktikatega seotud kultuurilistele semiosfääridele omaste narratiivide osana, rõhutavad käsitlemist vajava epistemoloogilise sisu mõõtmatut suurust ning korpuse funktsionaalne reduktsionism on üksnes esialgseks lähenemisviisiks valdkonnale, mis peaks valgustama panoraamset üldvaadet ja soodustama edasist arutelu ning arusaamist. 